\title{
Clinicohaematological study of anaemia in antenatal patients
}

\author{
Veena Gupta, Karishma Sharma*, Amrita Chaurasia
}

Department of Obstetrics and Gynecology, Motilal Nehru Medical College, Prayagraj, Uttar Pradesh, India

Received: 25 January 2020

Accepted: 28 February 2020

\section{*Correspondence:}

Dr. Karishma Sharma,

E-mail: drkarishmasharma@gmail.com

Copyright: (C) the author(s), publisher and licensee Medip Academy. This is an open-access article distributed under the terms of the Creative Commons Attribution Non-Commercial License, which permits unrestricted non-commercial use, distribution, and reproduction in any medium, provided the original work is properly cited.

\begin{abstract}
Background: According to WHO, approximately $75 \%$ of pregnant women in developing countries and $18 \%$ in developed countries are anaemic. In India prevalence of anaemia is reported to be $33 \%-89 \%$ and is one of the important causes of maternal morbidity and mortality. The present study was done with the objective to study the socio-demographic factors related to anemia and the distribution of different types of anaemia in antenatal patients.

Methods: A prospective analytical study was done on 205 pregnant females who presented with anemia $(\mathrm{Hb}<11$ $\mathrm{gm} / \mathrm{dl}$ ) in $1^{\text {st }}, 2^{\text {nd }}$ and early $3^{\text {rd }}$ trimester (up to 30 weeks of gestation) in the department of obstetrics and gynecology of Swaroop Rani Nehru Hospital, Prayagraj from September 2017 to September 2018.

Results: The rural background with lower socio-economic status comprised majority of the anemic patients (65.9\%) with the major cause being iron deficiency anemia (68.8\%). The patients mainly presented with anemia at late second or early third trimester $(82.4 \%)$. Clinical signs like pallor, oedema and symptoms like palpitations and dyspnoea were more associated with severe anemia than mild and moderate anemia.

Conclusions: Anemia prevention and prompt detection is the need of the hour with effective management. In India, major cause of anaemia are nutritional deficiencies which can be treated by proper diet and medications. The advises of routine iron supplementation during pregnancy, regardless of whether the mother is anemic or not, is strongly recommended by this study.
\end{abstract}

Keywords: Anaemia, Antenatal women, Hemoglobin, Iron deficiency anemia

\section{INTRODUCTION}

Anaemia in pregnancy is one of the most important cause of maternal morbidity and mortality in developing countries. Normally pregnancy is a state of "hydremic plethora". There is disproportionate increase of plasma volume as compared to red blood cell mass which leads to apparent reduction of $\mathrm{RBC}$, Haemoglobin, and haematocrit values. The dilution picture is normocytic normochromic- known as "Physiological Anaemia of Pregnancy".

According to $\mathrm{WHO}$, more than $75 \%$ of pregnant women in developing countries and $18 \%$ in developed countries are anaemic. In India prevalence of anaemia is reported to be $33 \%-89 \%$ which is more in the adolescent age group with variations in the different regions of the country. In India iron and folate deficiencies are the common causes of anaemia in pregnant women. ${ }^{1-5}$

According to $\mathrm{WHO}$, the acceptable haemoglobin level taken during pregnancy is $11 \mathrm{~g} / \mathrm{dl}$. Hb less than $11 \mathrm{~g} / \mathrm{dl}$ is considered to be anaemia. According to $\mathrm{CDC}$, criteria $\mathrm{Hb}$ $<11 \mathrm{~g} / \mathrm{dl}$ in first trimester, $\mathrm{Hb}<10.5 \mathrm{~g} / \mathrm{dl}$ in second trimester and $\mathrm{Hb}<11 \mathrm{~g} / \mathrm{dl}$ in third trimester is considered to be anaemic. Correspondingly, it causes a detectable change in the mean corpuscular haemoglobin $(\mathrm{MCH})$, mean corpuscular haemoglobin concentration (MCHC) and mean corpuscular volume (MCV). ${ }^{5-9}$

Iron deficiency in pregnancy is, in principle, identifiable, treatable and possibly preventable with iron 
supplementation. Systematic, screening and treatment for iron deficiency in pregnancy would improve maternal and infant outcomes. ${ }^{10-14} \mathrm{MCV}, \mathrm{MCH}$ and RDW are the iron parameters of $\mathrm{CBC}$ which is cost effective, easily accessible and can be useful in areas with limited resources and a high prevalence of the disease. ${ }^{15-16}$

The present study was done in the department of obstetrics and gynaecology of Swaroop Rani Nehru Hospital, Prayagraj, Uttar Pradesh, India procuring the complete clinico haematological work up of all anaemic antenatal patients in the $1^{\text {st }}, 2^{\text {nd }}$ and early $3^{\text {rd }}$ trimester up to 30 weeks with the objective to study the socio demographic factors related to anaemia and the distribution of different types of anaemia in antenatal patients.

\section{METHODS}

A prospective analytical study was done on 205 pregnant females who presented with anemia $(\mathrm{Hb}<11 \mathrm{gm} / \mathrm{dl})$ in $1^{\text {st }}, 2^{\text {nd }}$ and early $3^{\text {rd }}$ trimester (up to 30 weeks of gestation) attending antenatal clinics in the department of obstetrics and gynecology of Swaroop Rani Nehru Hospital, Prayagraj, Uttar Pradesh, India from September 2017 to September 2018.

\section{Inclusion criteria}

- Pregnant women willing to participate

- Pregnant women up to 30 weeks of gestational age

- Pregnant women with hemoglobin $<11$ gm/dl were included in the study.

\section{Exclusion criteria}

- Pregnant women not willing to participate, pregnant women in late third trimester $(>30$ weeks of gestation).

After an informed oral consent, thorough general, systemic and obstetrical examination was done. Further, blood sampling was done for hematological parameters such as complete hemogram analyzed by a semiautomatic three-part hematology analyzer (Medonic M series), peripheral blood smear examination by Leishman's staining and reticulocyte count which was calculated using a supravital stain new methylene blue. Females with hemoglobin $<9 \mathrm{~g} / \mathrm{dl}$ and reticulocyte count $2.5 \%$ or more and $\mathrm{MCV}<75 \mathrm{fl}$ were further investigated for serum iron, total iron binding capacity, serum ferritin and serum vitamin B12. Serum iron and TIBC was estimated on the semiautomatic chemical analyzer (Elitech Group Clinical System - Selectra Pro M). Total Ferritin was determined manually by ELISA procedure using BIOS human ferritin enzyme immunoassay test kit. The serum folate and serum vitamin B12 was determined by architect 1000 assay.

The pregnant females who had hemoglobin 9-11 g/dl with normal serum iron and serum ferritin were classified as Physiological anaemia of pregnancy, with $\mathrm{Hb}$ 7-9 g/dl with low serum ferritin were classified as moderate iron deficiency anaemia and with $\mathrm{Hb}<7 \mathrm{~g} / \mathrm{dl}$ with low serum iron, low serum ferritin were classified as severe anaemia.

\section{Statistical analysis}

Chi square test was used to calculate the association between anaemia and socio- demographic factors and other hematological parameters. Statistical significance was set at $95 \%$ confidence level ( $p$ - value of less than or equal to .05). Continuous data were summarized as mean \pm SD while discrete (categorical) in number and percentage. Continuous groups were compared by student's t test and categorical groups by Chi Square and ANOVA test.

\section{RESULTS}

The present study was done on 205 anaemic antenatal patients, out of which $141(68.8 \%)$ were Iron deficiency anaemia, $10(4.9 \%)$ Vitamin B12/Folic acid deficiency anaemia, 46 (22.4\%) Physiological anaemia of pregnancy and $8(3.9 \%)$ Thalassemia trait. Mild anaemia was found in $22.4 \%$, moderate anaemia in $57.1 \%$ and severe anaemia in $20.5 \%$ (Table 1 ).

Table 1: Distribution of type of anaemia.

\begin{tabular}{|c|c|c|c|c|c|}
\hline Type of anaemia & No. $(n=205)$ & $\%$ & $\begin{array}{l}\text { Mild 9- } \\
11 \text { g\% }\end{array}$ & $\begin{array}{l}\text { Moderate } \\
7-8.9 \mathrm{~g} \%\end{array}$ & $\begin{array}{l}\text { Severe } \\
<7 \mathrm{~g} \%\end{array}$ \\
\hline Iron deficiency anaemia & 141 & $68.8 \%$ & $2 \%$ & $103 \%$ & $36 \%$ \\
\hline Vitamin B12/Folic acid deficiency anaemia & 10 & $4.9 \%$ & - & $4 \%$ & $6 \%$ \\
\hline Physiological anaemia of pregnancy & 46 & $22.4 \%$ & $40 \%$ & $6 \%$ & - \\
\hline Thalassemia trait & 8 & $3.9 \%$ & $4 \%$ & $4 \%$ & - \\
\hline Percentage of anaemic females with severity of anamia & & & $22.4 \%$ & $57.1 \%$ & $20.5 \%$ \\
\hline
\end{tabular}

Table 2 shows that maximum patients, $140(68.3 \%)$ were in the age group between $20-25$ years, $50(24.4 \%)$ were in the age group between 26-30 years and $15(7.3 \%)$ were between $31-35$ years. The mean age of the patients was $24.81 \pm 3.11$. 
Table 2: Age at pregnancy with anaemia.

\begin{tabular}{|lll|}
\hline Age in years & No. $(\mathbf{n}=\mathbf{2 0 5})$ & $\%$ \\
\hline $20-25$ years & 140 & $68.3 \%$ \\
\hline $26-30$ years & 50 & $24.4 \%$ \\
\hline $31-35$ years & 15 & $7.3 \%$ \\
\hline Mean & & $24.81 \pm 3.11$ \\
\hline
\end{tabular}

Table 3 shows that out of $140(68.3 \%)$ anaemic pregnant women who were in the age group between $20-25$ years, $95(46.3 \%)$ had $\mathrm{Hb}>7 \mathrm{~g} \%$ and 45 (22\%) Hb $<7 \mathrm{~g} \% .50$ $(24.4 \%)$ women were found to be in the age group of 2630 years out of which $17(8.3 \%)$ had $\mathrm{Hb}>7 \mathrm{~g} \%$ and 33 (16.1\%) had $\mathrm{Hb}<7 \mathrm{~g} \%$. Out of $15(7.3 \%)$ women between the age group of 31-35 years, all of them had $\mathrm{Hb}$ $>7 \mathrm{~g} \%$. The mean age of pregnancy was $24.81 \pm 3.11$.

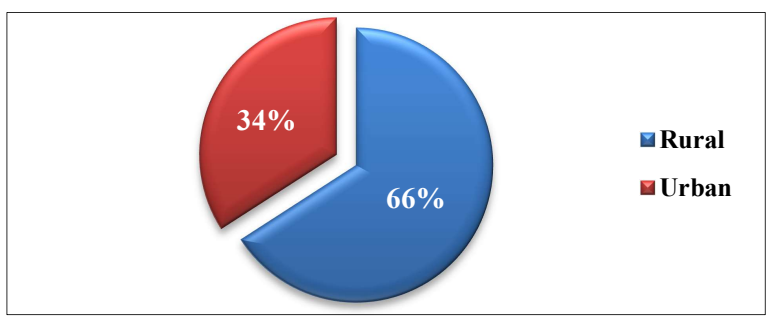

Figure 1: Relationship of domicile of patient with anaemia.

Table 3: Relationship of age in pregnancy with severity of anaemia.

\begin{tabular}{|c|c|c|c|c|c|c|}
\hline \multirow[t]{2}{*}{$\begin{array}{l}\text { Age at pregnancy } \\
\text { (years) }\end{array}$} & \multicolumn{2}{|c|}{$\begin{array}{l}\text { No. of pregnant females } \\
(n=205)\end{array}$} & \multicolumn{2}{|c|}{$\begin{array}{l}\text { No. of pregnant females } \\
\text { with } \mathrm{Hb}>7 \mathrm{~g} \%\end{array}$} & \multicolumn{2}{|c|}{$\begin{array}{l}\text { No. of pregnant females } \\
\text { with } \mathrm{Hb}<7 \mathrm{~g} \%\end{array}$} \\
\hline & No. & $\%$ & No. & $\%$ & No. & $\%$ \\
\hline $20-25$ & 140 & $68.3 \%$ & 95 & $46.3 \%$ & 45 & $22 \%$ \\
\hline $26-30$ & 50 & $24.4 \%$ & 17 & $8.3 \%$ & 33 & $16.1 \%$ \\
\hline $31-35$ & 15 & $7.3 \%$ & 15 & $7.3 \%$ & $0 \%$ & - \\
\hline Total & 205 & & 127 & & $78 \%$ & \\
\hline Mean & & $24.81 \pm 3.11$ & & & & \\
\hline
\end{tabular}

* For simplicity purpose, mild and moderate anaemia have been included in one group ( $\mathrm{Hb}>7 \mathrm{~g} \%)$.

Figure 1 shows that $135(65.9 \%)$ women were from the rural background whereas $70(34.1 \%)$ belonged to the urban background.

Table 4: Socioeconomic status.

\begin{tabular}{|lll|}
\hline Socioeconomic status & \multicolumn{2}{l|}{ Study group $(\mathbf{n}=\mathbf{2 0 5})$} \\
\hline & No. & $\mathbf{\%}$ \\
\hline Upper middle class & 18 & $8.8 \%$ \\
\hline Middle class & 50 & $24.4 \%$ \\
\hline Lower middle class & 23 & $11.2 \%$ \\
\hline Lower class & 114 & $55.6 \%$ \\
\hline
\end{tabular}

Table 4 shows that out of 205 antenatal women, 18(8.8\%) belonged to upper middle class, $50(24.4 \%)$ to middle class, $23(11.2 \%)$ to lower middle class and $114(55.6 \%)$ to lower class.

Table 5: Gestational age at presentation (in weeks).

\begin{tabular}{|l|lr|}
\hline Gestational age (in weeks) & No. $(\mathbf{n}=\mathbf{2 0 5})$ & $\%$ \\
\hline$\leq 12$ weeks & 9 & $4.4 \%$ \\
\hline $13-20$ weeks & 27 & $13.2 \%$ \\
\hline $21-30$ weeks & 169 & $82.4 \%$ \\
\hline Mean & & $24.11 \pm 4.22$ \\
\hline
\end{tabular}

Table 5 shows that out of 205 anemic pregnant women, 9 $(4.4 \%)$ presented with gestational age $<12$ weeks, 27
(13.2\%) had gestational age between 13 to 20 weeks whereas majority $169(82.4 \%)$ had gestational age between 21 to 30 weeks. The mean gestational age at presentation was $24.11 \pm 4.22$ weeks.

Table 6: Severity of anemia with clinical symptoms.

\begin{tabular}{|l|ll|l|}
\hline Clinical symptoms & \multicolumn{2}{|l|}{ No. of women } & p value \\
\hline Pallor & No. & $\%$ & \\
\hline Yes & 79 & $38.5 \%$ & \multirow{2}{*}{0.004} \\
\hline No & 126 & $61.5 \%$ & \\
\hline Edema & & & \\
\hline Yes & 38 & $18.5 \%$ & \multirow{2}{*}{0.03} \\
\hline No & 167 & $81.5 \%$ & \\
\hline Palpitations & & & \\
\hline Present & 23 & $11.2 \%$ & \multirow{2}{*}{0.03} \\
\hline Absent & 182 & $88.8 \%$ & \\
\hline Dyspnoea & & & \\
\hline Present & 27 & $13.2 \%$ & \multirow{2}{*}{0.03} \\
\cline { 1 - 2 } Absent & 178 & $86.8 \%$ & \\
\hline
\end{tabular}

Table 6 shows that out 205 patients, 79 (38.5\%) had pallor and $126(61.5 \%)$ had no pallor. The $\mathrm{p}$ value was significant 0.004 . Edema was found in 38(18.5\%) patients and $167(81.5 \%)$ had no edema. The $\mathrm{p}$ value was significant 0.03 . Palpitations was found in $23(11.2 \%)$ and $182(88.8 \%)$ patients had no palpitations. The $p$ value was significant 0.03 . Dyspnoea was found in $27(13.2 \%)$ 
and $178(86.8 \%)$ had no symptoms of dyspnoea. The $p$ value was significant 0.03 .

Table 7 show the distribution of anaemic pregnant females according to blood indices. Out of 205 anaemic pregnant women $46(22.5 \%)$ had MCV below normal range, $137(66.8 \%)$ had MCV in the normal range and 22 (10.7\%) had MCV above normal range. 145 (70.7\%) patients had $\mathrm{MCH}$ below normal range and $60(29.3 \%)$ patients had $\mathrm{MCH}$ in the normal range. 160 (78\%) patients had MCHC below normal range and 45 (22\%) had MCHC in the normal range.

Table 7: Distribution of anemic females according to blood indices.

\begin{tabular}{|c|c|c|c|c|c|c|}
\hline Blood indices & \multicolumn{2}{|c|}{ Below normal range } & \multicolumn{2}{|c|}{ Normal range } & \multicolumn{2}{|c|}{ Above normal range } \\
\hline & No. & $\%$ & No. & $\%$ & No. & $\%$ \\
\hline $\operatorname{MCV}(75-95$ fl) & 46 & $22.5 \%$ & 137 & $66.8 \%$ & \multirow{3}{*}{22} & \multirow{3}{*}{$10.7 \%$} \\
\hline MCH (27-32 pg) & 145 & $70.7 \%$ & 60 & $29.3 \%$ & & \\
\hline MCHC (33-36 g/dl) & 160 & $78 \%$ & 45 & $22 \%$ & & \\
\hline
\end{tabular}

Table 8: Comparison of haematological parameters between mild, moderate and severe anaemia on the basis of haemoglobin.

\begin{tabular}{|lllll|}
\hline \multirow{2}{*}{ Parameter } & \multicolumn{2}{l|}{ Subtypes of anaemia } & & \\
& Mild (Hb 9-11 g \%) & Moderate (Hb 7-8.9 g \%) & Severe Hb (<7 g \%) & p value \\
\hline Hb $(>11 \mathrm{~g} \%)$ & $9.39 \pm 0.26$ & $8.15 \pm 1.25$ & $6.02 \pm 0.95$ & 0.001 \\
\hline RBC $\left(3.5-5.5 \times 10^{12} / \mathrm{L}\right.$ & $4.30 \pm 0.38$ & $3.50 \pm 0.41$ & $2.86 \pm 0.24$ & 0.0001 \\
\hline RDW $(11.5-14.5 \%)$ & $15.29 \pm 1.3$ & $16.40 \pm 2.35$ & $17.51 \pm 3.10$ & 0.001 \\
\hline MCV $(75-95 \mathrm{fl})$ & $83.43 \pm 7.6$ & $78.24 \pm 9.48$ & $72.11 \pm 13.13$ & 0.001 \\
\hline MCH $(28-32 \mathrm{pg})$ & $28.24 \pm 2.7$ & $24.83 \pm 2.35$ & $23.16 \pm 3.21$ & 0.0001 \\
\hline MCHC (33-36 g/dl) & $33.03 \pm 0.93$ & $29.65 \pm 1.28$ & $24.45 \pm 0.99$ & 0.0001 \\
\hline S.Iron $(40-150 \mathrm{ug} / \mathrm{dl})$ & $56.33 \pm 14.64$ & $40.26 \pm 12.21$ & $23.74 \pm 4.71$ & 0.0001 \\
\hline S.Ferritin $(15-150 \mathrm{ng} / \mathrm{ml})$ & $19.00 \pm 26.54$ & $10.32 \pm 17.31$ & $4.035 \pm 0.82$ & 0.0001 \\
\hline TIBC $(200-400 \mathrm{ug} / \mathrm{dl})$ & $323.58 \pm 64.51$ & $400.46 \pm 28$ & $477.7 \pm 32.75$ & 0.0001 \\
\hline
\end{tabular}

Table 9: Association of subtypes of anaemia with haematological parameters.

\begin{tabular}{|c|c|c|c|c|c|c|c|}
\hline \multirow{3}{*}{$\begin{array}{l}\text { Haematological } \\
\text { parameters }\end{array}$} & \multicolumn{6}{|c|}{ Subtype of anaemia } & \multirow{3}{*}{ p value } \\
\hline & \multicolumn{2}{|c|}{$\begin{array}{l}(\mathrm{n}=46) \text { mild } \\
(\mathrm{Hb} 9-11 \mathrm{g \%})\end{array}$} & \multicolumn{2}{|c|}{$\begin{array}{l}\text { (n= 117) moderate } \\
(\mathrm{Hb} 7-8.9 \mathrm{~g} \%)\end{array}$} & \multicolumn{2}{|c|}{$\begin{array}{l}(\mathrm{n}=42) \text { severe } \\
(\mathrm{Hb}<7 \mathrm{~g} \%)\end{array}$} & \\
\hline & No. & $\%$ & No. & $\%$ & No. & $\%$ & \\
\hline \multicolumn{7}{|c|}{ Serum iron (40-150 ug/dl) } & \multirow{3}{*}{0.001} \\
\hline Abnormal & 9 & $19.6 \%$ & 68 & $58.1 \%$ & 42 & $100 \%$ & \\
\hline Normal & 37 & $80.4 \%$ & 49 & $41.9 \%$ & - & $0 \%$ & \\
\hline \multicolumn{7}{|c|}{ Serum ferritin $(15-150 \mathrm{ng} / \mathrm{ml})$} & \multirow{3}{*}{0.04} \\
\hline Abnormal & 42 & $91.3 \%$ & 113 & $96.6 \%$ & 42 & $100 \%$ & \\
\hline Normal & 4 & $8.7 \%$ & 4 & $3.4 \%$ & - & $0 \%$ & \\
\hline \multicolumn{7}{|c|}{ TIBC (200-400 ug/dl) } & \multirow{3}{*}{0.001} \\
\hline Abnormal & - & $0 \%$ & 47 & $40.2 \%$ & 42 & $100 \%$ & \\
\hline Normal & 46 & $100 \%$ & 70 & $59.8 \%$ & - & $0 \%$ & \\
\hline \multicolumn{7}{|c|}{ Serum VitB12 $(200-400 \mathrm{pg} / \mathrm{ml})$ mean value $=324.85 \pm 107.49$} & \multirow{3}{*}{0.003} \\
\hline Abnormal & - & $0 \%$ & 6 & $5.1 \%$ & 9 & $21.4 \%$ & \\
\hline Normal & 46 & $100 \%$ & 111 & $94.9 \%$ & 33 & $78.6 \%$ & \\
\hline \multicolumn{7}{|c|}{ Serum folate $(2-20 \mathrm{ng} / \mathrm{ml})$ mean value $=5.21 \pm 1.19$} & \multirow{3}{*}{0.001} \\
\hline Abnormal & - & $0 \%$ & 4 & $3.4 \%$ & 6 & $14.3 \%$ & \\
\hline Normal & 46 & $100 \%$ & 113 & $96.6 \%$ & 36 & $85.7 \%$ & \\
\hline
\end{tabular}

Table 8 shows that the mean value of $\mathrm{Hb}$ in mild anaemia was $9.39 \pm 0.26$, in moderate anaemia $8.15 \pm 1.25$ whereas in severe anaemia it was $6.02 \pm 0.95$. Likewise, the mean value of $\mathrm{RBC}$ count was $4.30 \pm 0.38$ in mild anaemia whereas in moderate anaemia it was $3.50 \pm 0.41$ and in severe anaemia it was $2.86 \pm 0.24$. The mean value of 
RDW in mild anaemia was $15.29 \pm 1.3$ whereas in moderate anaemia it was $16.40 \pm 2.35$ and in severe anaemia, $17.51 \pm 3.10$. Mean MCV in mild anaemia was $83.43 \pm 7.6$, in moderate was $78.24 \pm 9.48$ and in severe anaemia was $72.11 \pm 13.13$. The $p$ value came out to be significant $=0.001$. The mean of $\mathrm{MCH}$ in mild anaemia came to be $28.24 \pm 2.7$, in moderate anaemia $24.83 \pm 2.35$ and in severe anaemia it was $23.16 \pm 3.21$. The mean value of MCHC in mild anaemia came out to be $33.03 \pm 0.93$, in moderate anaemia it was $29.65 \pm 1.28$ and in severe anaemia $24.45 \pm 0.99$. The mean Serum iron value in mild anaemia was $56.33 \pm 14.64$, in moderate anaemia was $40.26 \pm 12.21$ and in severe anaemia was $23.74 \pm 4.71$. The mean of serum ferritin in mild anaemia was $19.00 \pm 26.54$ in moderate anaemia was $10.32 \pm 17.31$ and in severe anaemia was $4.035 \pm 0.82$. The mean value of serum TIBC in mild anaemia was $323.58 \pm 64.51$, in moderate anaemia was $400.46 \pm 28$ and in severe anaemia it was $477.7 \pm 32.75$.

Table 9 shows that 205 anaemic antenatal patients were grouped under mild moderate and severe anaemia on the basis of haemoglobin and were evaluated further on the basis of Serum iron, ferritin, TIBC, vitamin B12 and folate levels. 46 patients were classified as having mild anaemia in which abnormality was detected in serum iron in $9(19.6 \%)$ patients, serum ferritin in $42(91.3 \%)$ patients while no abnormality was detected in TIBC, vitamin B12 and folate levels. 117 patients were detected as having moderate anaemia which were further analysed on the same basis as above. Abnormal serum iron levels were found in $68(58.1 \%)$ patients, abnormal serum ferritin was found in $113(96.6 \%)$ patients, TIBC was found to be abnormal in $47(40.2 \%)$ patients, and 6 $(5.1 \%)$ patients had abnormal serum vitamin B12 levels and abnormal serum folate levels were detected in 4 (3.4\%) patients. 42 patients out of 205 had severe anaemia which on further analysis showed that all 42 $(100 \%)$ patients had abnormal serum iron, serum ferritin and TIBC levels. 9 (21.4\%) patients had abnormal serum vitamin B12 levels and 6 (14.3\%) had abnormal serum folate levels. The distinction made between the mild, moderate and severe category of anaemia on the basis of above parameters had a significant $\mathrm{p}$ value in every case i.e. serum iron $(p=0.001)$, serum ferritin $(p=0.04)$, TIBC $(\mathrm{p}=0.001)$, serum vitamin B12 $(\mathrm{p}=0.003)$ and serum folate $(\mathrm{p}=0.001)$.

\section{DISCUSSION}

Ante partum anaemia is a very important issue that needs aggressive attention to treat. India contributes to $80 \%$ of maternal deaths caused by anaemia in South Asia. In this study $68.8 \%$ patients had iron deficiency anaemia, $4.9 \%$ had VitB12/Folic acid deficiency and $22.4 \%$ had physiological anaemia of pregnancy which is similar to the study by Tripathi $\mathrm{R}$ et al, in which iron deficiency was an important cause of anaemia (48.1\%). ${ }^{9}$ A similar prevalence of anemia was found in North Indian region in the study done by Somdutta et al. ${ }^{10}$ This study findings also correlated with studies done by Sinha $\mathrm{M}$ et al, in which $65 \%$ of patients had iron deficiency anemia, $18.3 \%$ had dimorphic anemia and $5 \%$ had megaloblastic anemia. $^{11}$

In this study maximum patients belonged to the age group of 20- 25 years with the mean age group of $24.81 \pm 3.11$. The findings of this study were comparable to Dutta $\mathrm{S}$ et al and Ugunju et al, who found that most anemic women were in their twenties with age group of 21-24 years. ${ }^{10,12}$ Kumar et al, in his study found the mean age of anemic population to be $24.12 \pm 3.75$ years which correlated with this study. ${ }^{6}$

In this study the prevalence of anemia was maximum in the age group between 20-25 years with moderate anemia. This could be due to pregnancy in young age and most of them being only primigravida; the demand of iron is more in this period of growth which is further augmented due to pregnancy. Severe anemia in this study was more as compared to other studies because the study institution is a tertiary referral institution. This study was discordant with the study done by Bereka et al, where the antenatal women above 35 years were anemic. ${ }^{1}$ Vivek $\mathrm{RG}$ et al, in their study observed a high prevalence of anemia with majority (50.4\%) having moderate degree of anemia $(\mathrm{Hb}=7-10 \mathrm{~g} \%)$ and $7 \%$ had severe anemia. ${ }^{7}$

In this study we found that the people belonging to the rural community $135(65.9 \%)$ were more anemic as compared to people from urban areas $70(34.1 \%)$. This is in accordance with a study done by Kundap RP et al, and Shedole DT et al. ${ }^{2,3}$ The high prevalence of anemia in rural population can be attributed to their food habits, hygiene, lower literacy rates and limited access to the health care system. In this study $55.6 \%$ patients were from the lower socio-economic status. Over the years various other studies have also shown significant association of anaemia with lower socio-economic class like Fullerton et al, and Bodnar LM et al. ${ }^{13,14}$

In this study, the mean gestational age of presentation with anaemia was $24.11 \pm 4.22$ weeks which is similar to the study done by Taner CE et al, where they found the prevalence of anaemia to be more in the antenatal women in later pregnancy than in early pregnancy. ${ }^{4}$ Contrary to this, Kumar V et al, found the antenatal women in the $1^{\text {st }}$ trimester to be more anaemic as compared to late trimester. ${ }^{6}$ Low antenatal care coverage at the rural Primary health care center coupled with poor screening for anaemia without appropriate therapy might be the contributing factors for the increased prevalence in later half.

In this study, the mean value of $\mathrm{MCV}, \mathrm{MCH}$ and $\mathrm{MCHC}$ were on a lower range in severe and moderate anaemia than in mild anaemia and $\mathrm{p}$ value was also found to be very significant $(0.001)$ which is similar to the study by Jadhav MV et al, who found that highest diagnostic accuracy in correctly classifying anaemia into etiological 
groups was offered by $\mathrm{MCH}$ followed by $\mathrm{MCV}, \mathrm{MCHC}$, RDW. ${ }^{5}$ On the contrary, Broek VD et al, examined the diagnostic accuracy of iron parameters like MCV and found it to be quite low. ${ }^{16}$

In this study, the lower values of serum iron and ferritin in anaemic patients came out to be statistically significant and found to be very much diagnostic of iron deficiency anaemia. Out study was supported by Shah et al, where serum ferritin was normal in $39.2 \%$ anaemic pregnant women while $60 \%$ had below normal range. ${ }^{8}$ Similarly, in another study by, Dreyfuss MI et al, $83 \%$ of the pregnant women with mild anaemia and $100 \%$ of the pregnant females with moderate anaemia had low serum ferritin. ${ }^{15}$

\section{CONCLUSION}

- The major cause of anemia in majority of the population was iron deficiency anemia with a prevalence of $68.8 \%$ with most of the patients in the age group between $20-25$ years $(68.3 \%, 24.81 \pm 3.11)$. It may be due to increased demand during adolescence which gets augmented because of pregnancy.

- The rural background comprised majority of the anemic patients $(65.9 \%)$. This may have been because of lack of facilities and health care system in these areas. The severity of anemia was inversely proportional to socioeconomic class maybe because of lack of antenatal check-ups.

- The patients mainly presented with anemia at late second or early third trimester $(82.4 \%)$. This may have occurred as patients in the late gestation might have shown up for the first time and would not have taken any health supplementation from the beginning of their pregnancy.

Anemia prevention is the need of the hour and needs several programmes along with effective management for detection. In India, major cause of anaemia are nutritional deficiencies which can be treated by medications. The advice of routine iron supplementation during pregnancy, regardless of whether the mother is anaemic or not, is strongly recommended by this study.

\section{ACKNOWLEDGMENTS}

Authors would like to thank Prof. and Head (Dr.) Amrita Chaurasiya for her constant motivation and support and colleagues from the department of obstetrics and gynaecology and pathology for their cooperation.

Funding: No funding sources Conflict of interest: None declared

Ethical approval: The study was approved by the Institutional Ethics Committee

\section{REFERENCES}

1. Bereka SG, Gudeta AN, Reta MA, Ayana LA. Prevalence and associated risk factors of anemia among pregnant women in rural part of JigJiga City, Eastern Ethiopia: a cross sectional study. J Preg Child Health. 2017;4:337.

2. Shedole DT, Vidya GS, Suryakantha AH, Vijaykumar B. A comparative study on prevalence of anaemia among urban and rural adolescent high school girls of Davangere, Karnataka. Int J Community Med Public Health. 2017;4:4638-43.

3. Kundap RP, Dadewar A, Singru S, Fernandez K. A comparative study of prevalence of iron deficiency anaemia in antenatal women from urban and rural area of Pune, India. Ntl $\mathrm{J}$ Community Med. 2016;7(5):351-4.

4. Taner CE, Ekin A, Solmaz U. Prevalence and risk factors of anemia among pregnant women attending a high-volume tertiary care center for delivery. J Turkish German Gynecol Assoc. 2015;16(4):231-6.

5. Jadhav MV, Agarwal SA, Kadgi NV, Khedkar SS, Kulkarni KK, Kudrimoti JK. Utility of automated $\mathrm{RBC}$ parameters in evaluation of anemia Inter $\mathrm{J}$ Healthcare Biomed Res. 2015;3(3):170-81.

6. Kumar V, Sunderam S, Haider S, Kashyap V. A study on status of anaemia in pregnant women attending urban health training centre, RIMS, Ranchi. Indian J Comm Health. 2014;26, Suppl S2:112-7.

7. Viveki RG, Halappanavar AB, Viveki PR, Halki SB, Maled VS, Deshpande PS. Prevalence of anaemia and its epidemiological determinants in pregnant women. Al Ameen J Med Sci. 2012;5(3):216-23.

8. Shah AR, Patel ND, Shah MH. Hematological parameters in anaemic pregnant women attending the antenatal clinic of rural teaching hospital. Innov J Med Health Sci. 2012;2:70-3.

9. Tripathi R, Tyagi S, Singh T, Dixit A, Manju, Mala YM. Clinical evaluation of severe anemia in pregnancy with special reference to macrocytic anemia. J Obstet Gynaecol Res. 2012;38(1):203-7.

10. Somdatta P, Reddaiah VP, Singh B. Prevalence of anaemia in the postpartum period: a study of a North Indian village. 2009;39(4):211-5.

11. Sinha M. Spectrum of anemia in pregnant Indian women and importance of antenatal screening. Indian J Pathol Microbiol. 2006;49(3):373-5.

12. Ugunju, Broche DE, Gay C. Acute postpartum anemia. Clinical practice and interest of intravenous iron. Gynaecol Obstet Fertil. 2004;32613-69.

13. Harrold FW, Scott B. Anemia in poor class women with specific reference to pregnancy and menstruation. Am J Haematol. 2004;76:74-8.

14. Bodnar LM, Scanlon KS, Freedman DS, Siega-Riz AM, Cogswell ME. High prevalence of postpartum anemia among low-income women in the United States. Am J Obstet Gynecol. 2001;185(2):438-43.

15. Dreyfuss ML, Stoltzfus RJ, Shrestha JB. Hookworms, malaria and vitamin A deficiency 
among pregnant women in the plains of Nepal. $\mathrm{J}$ Nutr. 2000;130:2527-36.

16. Van den Broek NR. Let sky EA, White SA, Shenkin A. Iron status in pregnant women: which measurements are valid? $\mathrm{Br} \mathrm{J}$ Haematol. 1998;103(3):817-24.
Cite this article as: Gupta V, Sharma K, Chaurasia A. Clinicohaematological study of anaemia in antenatal patients. Int J Reprod Contracept Obstet Gynecol 2020;9:1603-9. 